\title{
Sentimen Investor Terhadap Peristiwa Terorisme Berbasis Fundamental Perusahaan (Studi pada Peristiwa Serangan Bom Sarinah 14 Januari 2016)
}

\author{
Wina Meilia Waspadiana Handoko ${ }^{1}$, Supramono ${ }^{*}$ \\ ${ }^{1}$ Fakultas Ekonomika dan Bisnis, Universitas Kristen Satya Wacana, Salatiga \\ *Penulis korespodensi; Email: supramono@staff.uksw.edu
}

\begin{abstract}
ABSTRAK
Sentimen investor adalah perasaan individu yang optimis atau pesimis yang berlebihan terhadap suatu situasi, yang menentukan terbentuknya harga di pasar saham. Penelitian ini bertujuan untuk menguji apakah terdapat sentimen investor atas serangan bom yang terjadi di kawasan Sarinah pada 14 Januari 2016. Penelitian ini melibatkan 65 perusahaan dari indeks LQ45 dan PEFINDO25 sebagai sampel, yang terbagi menjadi dua kelompok antara lain kelompok perusahaan dengan fundamental baik dan kelompok perusahaan dengan fundamental kurang baik. Hasil penelitian ini menunjukkan bahwa terdapat sentimen negatif atas peristiwa pengeboman pada 14 Januari 2016, bahkan terjadi overreaction pada kelompok perusahaan dengan fundamental kurang baik.
\end{abstract}

Kata kunci: Sentimen investor; fundamental perusahaan; over reaksi.

\begin{abstract}
Investor sentiment is an optimistic or excessively pessimistic individual feeling towards a situation, which determines the formation of prices in the stock market. This study aims to test whether there is investor sentiment for bomb attacks that occurred in Sarinah on January 14, 2016. This study involved 65 companies from the index LQ45 and PEFINDO25 as a sample, which is divided into two groups, the group of companies with good fundamentals and less good. The results of this study indicate that there is a negative sentiment over the bombing incident on January 14, 2016, even overreaction in the group of companies with fundamentally less good.
\end{abstract}

Keywords: Investor sentiment; company's fundamental; overreaction.

\section{PENDAHULUAN}

Selama beberapa tahun terakhir, terorisme telah menjadi fenomena global yang menjadi ancaman bagi banyak negara. Johnston dan Nedelescu (2005) menegaskan bahwa dalam jangka menengah peristiwa terorisme dapat merusak kepercayaan investor. Salah satu peristiwa terorisme yang terjadi di Indonesia adalah peristiwa pengeboman yang terjadi pada 14 Januari 2016 di kawasan Sarinah, Thamrin, Jakarta. Peristiwa tersebut berdampak pada ditutupnya beberapa pusat perbelanjaan di sekitar lokasi kejadian sehingga hal tersebut cukup mengganggu aktivitas bisnis di daerah tersebut. Selain itu peristiwa tersebut mempunyai dampak negatif terhadap pasar modal di Indonesia, pada pukul 11.29 IHSG mengalami penurunan 50,258 poin $(1,12 \%)$ ke $4.483,110$, kemudian pada perdagangan sesi pertama IHSG ditutup turun 77,859 poin $(1,72 \%)$ ke 4.459,320. Sedangkan indeks LQ45 ditutup merosot 17,830 poin (2,25\%) ke 775.471. Dari hasil perdagangan hari itu diperoleh sebanyak 38 saham mengalami peningkatan, 214 saham menurun, dan 54 saham stagnan (finance. detik.com, 14 Januari 2016).

Penelitian sebelumnya yang terkait dengan serangan terorisme di luar negeri antara lain Chen and Siems (2004); Drakos (2010); Kumar and Liu (2013) yang meneliti tentang efek terorisme di pasar modal global. Aurangzeb and Dilawer (2012) melakukan studi mengenai dampak terorisme terhadap return saham di Pakistan, dalam penelitian tersebut dipilih empat jenis teror yang digunakan yaitu pemboman, isolasi bersenjata, pembunuhan dan penyanderaan, penelitian tersebut menunjukkan bahwa pengembalian saham bereaksi negatif terhadap kegiatan terorisme yang terjadi. Baker 
(2014) membahas dampak terorisme terhadap industri pariwisata. Penelitian di Indonesia terkait dengan serangan teroris dilakukan oleh Utama and Hapsari (2012) menganalisis reaksi pasar modal akibat serangan bom teroris berdasarkan jenis industri dan kepemilikan saham asing. Meskipun beberapa studi telah dilakukan, tetapi masih menyisakan dua pertanyaan apakah sentimen negatif tersebut dialami oleh mayoritas perusahaan atau hanya terjadi pada perusahaan dengan karakateristik tertentu saja. Misalnya perusahaan dengan fundamental keuangan perusahaan yang kurang bagus. Selain itu apakah terdapat potensi terjadinya overreaction akibat peristiwa tersebut. Penelitian ini bertujuan untuk menjawab kedua pertanyaan tersebut.

\section{Sentimen Investor}

Fama (1970) menyatakan pasar berada dalam kondisi efisien jika harga selalu mencerminkan semua informasi yang tersedia. Kondisi pasar tersebut mengacu pada asumsi bahwa investor bertindak rasional. Investor dalam pengambilan keputusan menggunakan pertimbangan yang logis berdasarkan seluruh informasi yang dimilikinya. Informasi tersebut dapat berasal dari peristiwaperistiwa yang terjadi baik di dalam maupun luar perusahaan (Sirait et al. 2012). Sementara DeLong et. al (1990) mengungkapkan bahwa di pasar terdapat dua tipe investor: investor yang rasional yakni bebas sentimen dan investor tidak rasional adalah cenderung mengalami sentimen. Dua tipe investor tersebut bersaing di pasar dan menentukan harga serta return. Jika terjadi dominasi sentimen investor maka akan mengarah pada terbentuknya pasar yang tidak efisien.

Baker and Wurgler (2006) mendefinisikan sentimen investor adalah keyakinan tentang masa depan cash flow dan risiko investasi yang tidak didukung oleh fakta. Sedangkan Mehrani et al (2016) mengemukakan bahwa sentimen investor adalah perasaan individu yang optimis atau pesimis yang berlebihan terhadap suatu situasi. Kedua definisi tersebut memberi tekanan pada faktor psikologis yakni keyakinan atau perasaan terhadap situasi tertentu. Dalam kontek terorisme serangan bom maka dapat menimbulkan perasaan pesimis di kalangan investor terhadap masa depan perusahaan di Indonesia. Investor segera menjual sahamnya sehingga mengakibatkan harga saham akan mengalami penurunan atau terjadi sentimen negatif. Beberapa penelitian yang berhubungan serangan terorisme pernah dilakukan antara lain oleh Utama and Hapsari (2012); Kumar and Liu (2013); Aurangzeb and Dilawer (2012); Baker (2014); Najaf (2017) yang menemukan adanya sintemen negatif terhadap peristiwa terorisme. Berdasarkan hal tersebut, maka diajukan hipotesis sebagai berikut;

$\mathrm{H}_{1}$ : Terdapat sentimen negatif akibat terjadinya peristiwa serangan bom Sarinah pada 14 Januari 2016.

\section{Fundamental Perusahaan}

Pada pasar efisien, harga akan mencerminkan kondisi fundamental perusahaan. Perusahaan dengan kondisi fundamental bagus sahamnya cendrerung mengalami kenaikan begitu juga sebaliknya. Oleh karena itu fundamental perusahaan sering digunakan oleh investor untuk kepentingan pengambilan keputusan transaksi. Beberapa penelitian telah memberi bukti empirik bahwa kondisi fundamental perusahaan yang diukur dengan ratio keuangan seperti dividend yield, earning yield dan book-to-market ratio berpangaruh secara signifikan positip terhadap harga saham (Kheradyar, 2011; Menike,2016). Sedangkan ratio lainnya yang berhubungan protitabilitas seperti ROA, ROE, P/E and EPS juga memiliki pengaruh yang kuat terhadap harga saham (Arkan, 2016). Penelitian lainya menunjukan bahwa EVA dan EPS berpengaruh signifikan positif terhadap return saham (Amyulianthy and Ritonga 2016).

.Secara umum analisis fundamental terdiri dari tiga kategori yakni fundamental makro, fundamental industri dan fundamental perusahaan. Dalam penelitian ini pembahasannya dibatasi hanya pada fundamental perusahaan. Analisis fundamental perusahaan dapat digunakan untuk mengukur apakah perusahaan yang bersangkutan memiliki pertumbuhan yang bagus, memiliki posisi persaingan yang kuat dan memiliki kemampuan memenuhi kewajibanya. Analisis fundamental adalah landasan investasi (Drakopoulou,2015). Melalui analisis fundamental, investor dapat mengetahui nilai intrinksik perusahaan (Venkates, 2012).Investor akan cenderung membeli atau mempertahankan saham perusahan yang memiliki fundamental bagus dan sebaliknya akan melepaskan saham perusahaan dengan fundamental kurang bagus. Jika dikaitkan dengan peristiwa serangan bom yang merupakan "bad news" kemungkinan reaksi investor akan berbeda tergantung pada kondisi fundamental perusahaan. Saham-saham yang memiliki fundamental bagus diperkirakan tidak banyak terpengaruh peristiwa serangan bom tersebut. Berdasarkan uraian diatas, maka dirumuskan hipotesis sebagai berikut

$\mathrm{H}_{2}$ : Terdapat perbedaan sentimen investor atas peristiwa serangan bom Sarinah Sarinah pada 14 Januari 2016 berdasarkan fundamental keuangan perusahaan. 


\section{Overreaction}

Barberis et al. (1998) dikenal sebagai inisiator yang memodelkan sentimen investor untuk menjelaskan underreaction dan overreaction di pasar saham. Dalam model mereka, investor tidak menyadari bahwa return mengikuti random walk. Sebaliknya, percaya bahwa return mengikuti pengembalian rata-rata, atau tren. Sebelumnya De Bondt andThaler (1985) melalui hipotesis overreaction menyatakan bahwa pasar telah bereaksi berlebihan terhadap suatu informasi. Pada saat mendapatkan informasi yang dianggap baik pelaku pasar cenderung menetapkan harga saham terlalu tinggi, sedangkan pada saat menerima informasi yang buruk pelaku pasar cenderung menetapkan harga terlalu rendah. Ketika terjadi overreaction, harga akan terkoreksi dengan sendirinya sehingga terjadi pembalikan harga (price reversal). Dengan demikian pembalikan harga setelah munculnya suatu informasi baru merupakan petunjuk terjadinya overreaction (Yull and Kirmizi 2012).

Penelitian overreaction telah banyak diteliti dengan menggunakan periode waktu yang berbeda-beda. De Bondt dan Thaler (1985) telah mendokumentasikan. terjadinya overreaction dalam jangka panjang. Sementara beberapa penelitian lain telah menemukan terjadinya overreaction pada periode waktu yang relatif pendek, misalnya bulanan (Jegadeesh, 1990), mingguan (Lehman, 1990) dan harian (Yong Fang, 2013).

Bias koqnitif sering disebut sebagai penyebab terjadinya perilaku investor yang berlebihan (overreaction) dalam bertransaksi (Ali et al. 2011). Misalnya penelitian Raharja et. al (2017) membuktikan bahwa terdapat kaitan antara overconfidence dengan overreaction. Vinetha, and Krisnakumar (2015) menekankan bahwa penyebab terjadinya overreaction adalah investor lebih memberi perhatian pada informasi terkini dan mengabaikan fundamental perusahaan jangka panjang. Sementara Yong Fang (2013) menemukan hal yang menarik dalam penelitiannya bahwa ternyata investor cenderung underreaction terhadap good news dan overreaction terhadap bad news. Oleh karena itu peristiwa terorisme serangan bom sebagai bad news diperkirakan akan menimbulkan overreaction. Investor menjadi panik dan melakukan keputusan jual secara tergesa-gesa. Berdasarkan uraian diatas, maka diajukan hipotesis sebagai berikut

$\mathrm{H}_{3}$ : Terjadi overreaction pada saat terjadinya peristiwa serangan bom Sarinah pada 14 Januari 2016.

\section{METODE PENELITIAN}

\section{Desain Penelitian}

Penelitian ini dilakukan dengan menggunakan studi peristiwa (event study). Studi peristiwa digunakan untuk menemukan respon investor terhadap beragam peristiwa yang berbeda misalnya, pengumuman dividen, pengumuman merger dan akuisisi, dan pengumuman variabel ekonomi makro seperti defisit perdagangan, dengan menggunakan data pasar keuangan, studi peristiwa mengukur dampak dari peristiwa tertentu pada nilai perusahaan (MacKinlay 1997). Jika pengumuman tersebut mengandung informasi maka ditunjukkan dengan adanya perubahan harga dari sekuritas bersangkutan, sentimen investor dapat diukur dengan menggunakan return sebagai nilai perubahan harga atau dengan menggunakan abnormal return. Sebaliknya yang tidak mengandung informasi maka tidak akan memberikan abnormal return kepada pasar. Peristiwa atau event yang dipilih adalah peristiwa pengeboman yang terjadi di kawasan Sarinah, Thamrin, Jakarta pada 14 Januari 2016.

\section{Data dan Metode Pengumpulan Data}

Data yang digunakan dalam penelitian ini merupakan data sekunder yang diperoleh dari www.idx.co.id, finance.yahoo.com dan media masa, yang terdiri dari daftar perusahaan yang termasuk dalam LQ45 dan PEFINDO25, harga penutupan (closing prices) saham perusahaan LQ45 dan PEFINDO25, laporan keuangan perusahaan yang termasuk dalam LQ45 dan PEFINDO25, dan informasi tentang aksi korporasi yang dilakukan oleh perusahaan LQ45 dan PEFINDO25 selama periode penelitian.

\section{Pengukuran}

Untuk melihat dampak terjadinya peristiwa pengeboman yang terjadi di kawasan Sarinah pada 14 Januari 2016 terhadap sentimen investor di pasar modal dapat dilihat melalui average abnormal return (AAR) pada saham yang termasuk dalam indeks LQ45 dan PEFINDO25. Analisis terhadap overreaction dilakukan dengan melihat AAR pada saham yang termasuk dalam indeks LQ45 dan PEFINDO25 selama event window. Berdasarkan pengamatan selama event window tersebut, apabila abnormal return setelah hari peristiwa signifikan dan mengalami perubahan ke arah berlawanan atau ditandai dengan adanya pembalikan harga maka terjadi overreaction. 


\section{Populasi dan Metode Sampling}

Populasi dalam penelitian ini adalah seluruh perusahaan yang masuk dalam indeks LQ45 pada periode Januari 2016, yaitu sebanyak 45 perusahaan, dan perusahaan-perusahaan yang termasuk dalam indeks PEFINDO25 pada periode Januari 2016 sebanyak 25 perusahaan. Alasan digunakannya saham LQ45 sebagai populasi dalam penelitian ini adalah karena perusahaan yang termasuk dalam indeks LQ45 merupakan perusahaan besar yang memiliki likuiditas tinggi. Indeks PEFINDO 25 dipilih untuk mewakili perusahan kecil dan menengah yang memiliki likuiditas tinggi.

Dalam penelitian ini metode pengambilan sampel yang digunakan adalah purposive sampling. Dalam penelitian ini kriteria perusahaanperusahaan tersebut tidak sedang melakukan pembagian dividen, mengadakan RUPS, melakukan merger akuisisi, stock split ataupun aksi korporasi lainnya, sehingga sampel yang terpilih ini benar-benar menunjukkan bahwa nantinya return saham tersebut tidak terpengaruh oleh aksi-aksi lain selain peristiwa pengeboman pada 14 Januari 2016 sehingga terhindar confounding effectljoint effect. Berdasarkan kriteria tersebut seperti yang ditunjukkan pada tabel 1 maka dari 70 perusahaan didapatkanlah 65 perusahaan untuk menjadi sampel dalam penelitian ini.

Tabel 1. Proses Pengambilan Sampel

\begin{tabular}{lc}
\hline Keterangan & Jumlah \\
\hline $\begin{array}{l}\text { Jumlah sampel awal LQ45 } \\
\text { Pelanggaran Kriteria }\end{array}$ & 45 \\
\hline $\begin{array}{l}\text { Perusahahaan melakukan aksi korporasi RUPS } \\
\text { pada 7 - 29 Januari 2016 }\end{array}$ & $(2)$ \\
$\begin{array}{l}\text { Perusahahaan melakukan aksi korporasi } \\
\text { pembagian Dividen pada 7 - 29 Januari 2016 }\end{array}$ & $(1)$ \\
Jumlah sampel akhir LQ45 & 42 \\
Jumlah sampel awal PEFINDO25 & 25 \\
Pelanggaran Kriteria & \\
$\begin{array}{l}\text { Perusahahaan melakukan aksi korporasi RUPS } \\
\text { pada 7 - 29 Januari 2016 }\end{array}$ & $(1)$ \\
Perusahaan juga termasuk dalam indeks LQ45 & $(1)$ \\
Jumlah sampel akhir PEFINDO25 & 23 \\
\hline
\end{tabular}

Sumber: Data olah, 2016

\section{Tahapan Analisis Data.}

Tahapan analisis dilakukan dalam penelitian ini sebagai berikut: Pertama. menentukan event date yaitu hari pada saat kejadian 14 Januari 2016 $(\mathrm{t}=0)$ hingga 29 Januari $2016(\mathrm{t}=+11)$. Berbeda dengan event study terhadap peristiwa pengumuman dikeluarkan oleh perusahaan atau dikenal corporate action atau pengumuman yang berasal dari luar peristiwa perusahaan seperti pengumuman reshuffle kabinet yang dilakukan oleh Supramono et.al (2017), serangan teroris tidak memiliki kemungkinan kebocoran informasi (leakage information), sehingga to ditetapkan sebagai awal dari event window dan periode estimasi selama 100 hari sebelum event date

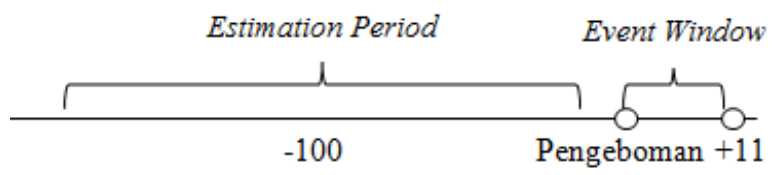

Kedua, melakukan pengujian hipotesis dengan melibatkan langkah-langkah analisis sebagai berikut:

(1) Menghitung return saham sesungguhnya saham LQ45 dan PEFINDO25

$\mathrm{R}_{\mathrm{j}, \mathrm{t}}=\frac{P_{j, t}-P_{j, t-1}}{P_{j, t-1}}$

Rj,t = Pendapatan Aktual saham $\mathrm{j}$ pada bulan $\mathrm{t}$

$\mathrm{Pj}, \mathrm{t}=$ Harga saham $\mathrm{j}$ pada bulan $\mathrm{t}$

Pj,t-1= Harga saham j pada bulan t-1

(2) Menghitung return pasar (Rm) pada saham pada saham LQ45 dan PEFINDO25

$\mathrm{R}_{\mathrm{m}, \mathrm{t}}=\frac{I H S G_{t}-I H S G_{t-1}}{I H S G_{t-1}}$

Rmt = Pendapatan pasar hari $\mathrm{t}$

IHSGt = Indeks Harga Saham pada bulan $\mathrm{t}$

IHSGt-1 = Indeks Harga Saham pada bulan t-1

(3) Menghitung abnormal return merupakan selisih antara actual return dengan expected return. Pada penelitian ini expected return dihitung dengan menggunakan metode sesuaian pasar (market adjusted model).

$\hat{R}_{\mathrm{it}}=\alpha_{j}+\beta_{j} R_{m t}$

$\mathrm{AR}_{\mathrm{jt}}=\mathrm{R}_{\mathrm{jt}}-\alpha_{j}+\beta_{j} R_{m t}$

$\hat{R}_{\mathrm{jt}}=$ expected return saham untuk perusahaan $\mathrm{j}$ pada periode ke-t

$R_{m t}=$ return indeks pasar pada periode t $\alpha_{j}$ dan $\beta_{j}$ diestimasi menggunakan OLS selama estimated period

$\mathrm{AR}_{\mathrm{jt}}=$ abnormal return saham untuk perusahaan $\mathrm{j}$ pada periode ke-t

(4) Menguji apakah peristiwa serangan terorisme yang terjadi tersebut memberikan dampak terhadap rata-rata abnormal return pada saham perusahaan LQ45 dan PEFINDO25 pada saat event window, t statistik (t hitung) untuk masing-masing periode dihitung dengan menggunakan AAR, dan standar deviasi AAR, sebagai berikut

$A A R_{n t}=\frac{\sum \mathrm{ARjt}}{N}$

Standar deviasi AAR dihitung dengan rumus, yaitu:

$\sigma_{n e}=\sqrt{\frac{\sum \sigma_{i e}^{2}}{N}}$

$N=$ Jumlah saham yang menjadi sampel 
$\sigma_{i e}=$ Nilai standar deviasi $\mathrm{AR}$ pada periode estimasi

Sehingga t statistik (t hitung) dinyatakan dengan rumus, yaitu:

$\mathrm{t}_{\text {hitung }}=\frac{A A R_{n t}}{\sigma_{n e}}$

(5) Memisahkan kelompok perusahaan dengan fundamental baik dan kurang baik, dilakukan berdasarkan PER dan EVA-nya. Dengan cara memisahkan sampel berdasarkan industri perusahaan-perusahaan tersebut maka dapat dihitung rasio keuangan rata-rata industrinya, baru setelah itu PER dan EVA setiap perusahaan dapat dibandingkan dengan PER dan EVA rata-rata industrinya sehingga didapatkan dua kelompok sampel yaitu perusahaan dengan fundamental baik apabila PER dan EVA perusahaan lebih tinggi dibandingkan PER dan EVA rata-rata industrinya begitu juga sebaliknya.

$$
\begin{aligned}
\text { PER }= & \frac{\text { harga } \text { saham }}{E P S} \\
\text { EVA }= & \text { NOPAT }- \text { biaya modal } \\
\text { EVA }= & \text { NOPAT }-(\text { WACC } \mathrm{x} \text { capital) } \\
\text { NOPAT }= & \text { laba bersih setelah pajak } \text { (net operat } \text { - } \\
& \text { ing profit after tax) } \\
\text { Capital }= & \text { total modal yang dinvestasikan } \\
\text { WACC }= & \text { biaya modal rata-rata tertimbang } \\
& \text { (weight average cost of capital) }
\end{aligned}
$$

Dimana

NOPAT $=$ Laba (rugi) usaha - pajak

$\mathrm{WACC}=\{(\mathrm{D} * \mathrm{Rd}) *(1-\mathrm{Tax})+(\mathrm{E} * \mathrm{Re})\}$

$\mathrm{D}=\frac{\text { total hutang }}{\text { total hutang dan ekuitas }} \times 100 \%$

$\mathrm{Rd}=\frac{\text { beban bunga }}{\text { total hutang }} \times 100 \%$

$\mathrm{E}=\frac{\text { total ekuitas }}{\text { total hutang dan ekuitas }} \times 100 \%$

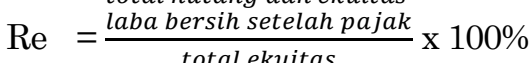

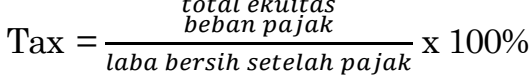

$\mathrm{D}=$ tingkat modal dari hutang

$\mathrm{Rd}=$ cost of debt

Tax $=$ tingkat pajak

$\mathrm{E}=$ tingkat modal dan equitas

$\operatorname{Re}=$ cost of equity

(6) Menguji apakah peristiwa serangan terorisme yang terjadi tersebut memberikan dampak terhadap rata-rata abnormal return pada kelompok perusahaan dengan fundamental baik dan yang kurang baik selama event window, $\mathrm{t}$ statistik (t hitung) untuk masing-masing periode dihitung dengan menggunakan AAR, dan standar deviasi AAR sama seperti dengan langkah (4); (7) Menganalisis pembalikan harga yang terjadi melalui grafik cumulative average $a b$ normal return (CAAR) dan nilai AAR pada hari setelah peristiwa apakah signifikan dan bernilai positif.

\section{HASIL PENELITIAN DAN PEMBAHASAN}

\section{Statistik Deskriptif}

Dalam statistik deskripsi, data yang disajikan berupa nilai maksimum, minimum, rata-rata dan standar deviasi dari abnormal return saham LQ45 dan PEFINDO25, selama event window yaitu pada hari pengeboman ( $\left.t_{0}\right)$ sampai dengan 11 hari setelah peristiwa $\left(t_{11}\right)$ dan selama 12 hari sebelum peristiwa pengeboman sebagai perbandingan. Berdasarkah hasil pengolahan data, seperti yang dapat dilihat pada Tabel 2 panel A menunjukkan bahwa selama event window pada saham LQ45 dan PEFINDO25 nilai minimum mengalami penurunan dari -0,078 menjadi -0,099. Nilai abnormal return terendah pada periode estimasi dimiliki oleh PT Sawit Sumbermas Sarana Tbk, sedangkan nilai abnormal return terendah pada saat event window dimiliki oleh PT Sri Rejeki Isman Tbk. Abnormal return maksimum pada periode estimasi dimiliki oleh PT Link Net Tbk, nilai maksimum sebelum dan setelah peristiwa pengeboman mengalami kenaikan dari maksimum 0,158 menjadi sebesar 0,164 yang dimiliki oleh PT Mitrabahtera Segara Sejati Tbk.

Nilai rata-rata selama event window mengalami penurunan sebelum peristiwa pengeboman sebesar -0,002 kemudian pada saat event window menjadi -0,004. Penurunan rata-rata abnormal return dari sebelum pengeboman dengan saat dan sesudah pengeboman sebesar -0,002 diduga terjadi sebagai dampak atas peristiwa pengeboman pada 14 Januari 2016, yang mengakibatkan terjadinya abnormal return negatif di pasar modal. Simpangan baku sesudah peristiwa tidak mengalami perubahan yang signifikan hanya sebesar 0,0001 dari 0,0251 menjadi 0,0252.

Dalam penelitian ini untuk memisahkan fundamental perusahaan antara perusahaan dengan fundamental baik dan yang kurang baik dilakukan dengan cara memisahkan sampel berdasarkan industri perusahaan-perusahaan tersebut kemudian dihitung PER dan EVA rata-rata industrinya, baru setelah itu PER dan EVA setiap perusahaan dapat dibandingkan dengan PER dan EVA rata-rata industrinya sehingga didapatkan dua kelompok sampel yaitu perusahaan dengan fundamental baik apabila PER dan EVA perusahaan lebih tinggi dibandingkan PER dan EVA rata-rata industrinya dan perusahaan dengan fundamental yang kurang baik yaitu apabila PER dan EVA perusahaan lebih rendah dibanding PER dan EVA rata-rata industrinya. Seperti yang ditunjukan oleh tabel 2 panel B diatas bahwa berdasarkan analisis yang telah dilakukan sebelumnya didapatkan 14 perusahaan masuk ke dalam 
negatif signifikan bagi investor. Selain itu pada

Tabel 2. Statistik Deskriptif

\begin{tabular}{|c|c|c|c|c|}
\hline \multicolumn{5}{|c|}{ Panel A: Abnormal Return } \\
\hline & Min & Max & Mean & Std. Dev \\
\hline Saat Event window & $-0,099$ & 0,164 & $-0,004$ & 0,0252 \\
\hline Sebelum Event window & $-0,078$ & 0,158 & $-0,002$ & 0,0251 \\
\hline \multicolumn{5}{|c|}{ Panel B : Pengelompokan Sampel } \\
\hline \multirow[b]{2}{*}{ Industri } & \multicolumn{2}{|c|}{ Rata-Rata Industri } & \multicolumn{2}{|c|}{ Fundamental Perusahaan } \\
\hline & PER & $\begin{array}{c}\text { EVA } \\
\text { (Dalam Jutaan Rp) }\end{array}$ & Baik $^{*}$ & Kurang Baik ${ }^{* *}$ \\
\hline Bahan Tambang & 10,093 & 330.678 & 0 & 4 \\
\hline Hasil Industri untuk Konsumsi & 25,611 & 907.185 & 2 & 5 \\
\hline Industri Dasar dan Bahan Kimia & 24,147 & 405.631 & 1 & 7 \\
\hline Industri Lainnya & 16,713 & 1.887 .133 & 1 & 3 \\
\hline Keuangan & 13,167 & 16.428 .825 & 0 & 3 \\
\hline Perdagangan, Jasa, Investasi & 56,405 & 288.627 & 0 & 14 \\
\hline Pertanian & 25,935 & 154.473 & 2 & 2 \\
\hline Properti, Real Estate & 20,026 & 311.257 & 4 & 10 \\
\hline Transportasi & $-163,487$ & 402.132 & 4 & 3 \\
\hline Total & & & 14 & 51 \\
\hline
\end{tabular}

Keterangan: *Baik, jika PER \& EVA > rata-rata industri; **Kurang baik, jika PER \& EVA < rata-rata industri

kelompok perusahaan dengan fundamental baik sedangkan 51 sisanya termasuk dalam kelompok perusahaan dengan fundamental perusahaan yang kurang baik.

Grafik 1 menggambarkan pola pergerakan $A A R$ yang terjadi selama periode pengamatan. Dapat dilihat bahwa secara berturut-turut pada saat terjadinya peristiwa ( $\left.t_{0}\right)$ sampai dengan dua hari setelah peristiwa ( $\left.\mathrm{t}_{2}\right)$ nilai AAR bernilai negatif, dengan nilai terendah terjadi pada $t_{0}$ sebesar -0,012. Kemudian pada hari ketiga setelah peristiwa ( $\mathrm{t}_{3}$ ) AAR mengalami peningkatan kembali, kenaikan nilai AAR tersebut dikarenakan pasar sudah kembali normal setelah terjadinya peristiwa pengeboman yang telah terjadi sebelumnya.

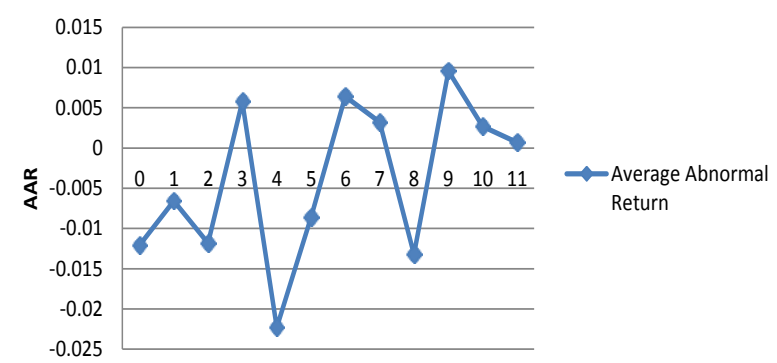

Grafik 1. Average Abnormal Return

\section{Analisis}

Hasil pengolahan data AAR dari indeks saham LQ 45 dan PEFINDO25 selama event window pada Tabel 3, menunjukkan bahwa pada saat terjadinya pengeboman pada 14 Januari 2016 diperoleh nilai AAR sebesar -0,012 thitung sebesar 3,142. Dengan demikian peristiwa pengeboman di Sarinah pada 14 Januari 2016 menghasilkan AAR
Tabel 3 juga memperlihatkan bahwa terdapat sentimen negatif dan signifikan pada tingkat $5 \%$ secara berturut-turut juga terjadi pada satu hari setelah peristiwa pengeboman terjadi ( $\left.t_{1}\right)$ sampai dengan hari kedua setelah peristiwa $\left(t_{2}\right)$. Tabel 3 tersebut juga menunjukkan bahwa secara statistik AAR signifikan negatif juga terjadi pada $t_{4}$ dengan thitung $-5,778$, t5 dengan thitung $-2,236$, dan ts dengan thitung $-3,421$. Hasil tersebut menunjukkan bahwa secara statistik pada sebagian besar event window terjadi sentimen negatif akibat peristiwa pengeboman di Sarinah pada 14 Januari 2016.

Dari hasil perhitungan AAR pada event window menunjukkan bahwa peristiwa pengeboman di Sarinah pada 14 Januari 2016 terdapat kandungan informasi yang kemudian direspon secara negatif oleh pasar. Selain itu, dengan diperolehnya hasil tersebut menyatakan bahwa $\mathrm{H}_{1}$ diterima, yang berarti bahwa terdapat sentimen negatif pada pasar modal akibat terjadinya peristiwa serangan bom.

Hipotesis yang selanjutnya akan dibuktikan adalah adakah perbedaan sentimen investor atas peristiwa pengeboman pada 14 Januari 2016 pada kelompok perusahaan dengan fundamental baik dan kelompok perusahaan dengan fundamental kurang baik. Untuk membuktikan hal itu maka dilakukan pengujian abnormal return yang dibedakan berdasarkan fundamental perusahaan. Tabel 3 di atas menunjukkan bahwa pada saat peristiwa pengeboman ( $\left.t_{0}\right)$ tidak terdapat sentimen negatif yang signifikan pada kelompok perusahaan dengan fundamental baik, bahkan keadaan tersebut terjadi selama 2 hari berturut-turut yaitu pada $t_{0}$ dengan thitung $-1,381$ dan $t_{1}$ dengan thitung 0,047. Kondisi tersebut berbanding terbalik pada kelompok perusahaan dengan fundamental kurang baik yang memperlihatkan sentimen negatif aki- 
Tabel 3. Tabel Signifikansi Average Abnormal Return Selama Periode Pengujian

\begin{tabular}{cccccccccc}
\hline & \multicolumn{3}{c}{ Keseluruhan } & \multicolumn{3}{c}{ Fundamental Baik } & \multicolumn{3}{c}{ Fundamental Kurang Baik } \\
\hline $\mathrm{t}$ & AAR & CAAR & THitung & AAR & CAAR & THitung & AAR & CAAR & THitung \\
\hline 0 & $-0,012$ & $-0,012$ & $-3,142^{*}$ & $-0,011$ & $-0,011$ & $-1,381$ & $-0,012$ & $-0,012$ & $-2,811^{* * *}$ \\
1 & $-0,007$ & $-0,019$ & $-1,704^{*}$ & 0,000 & $-0,011$ & 0,047 & $-0,008$ & $-0,02$ & $-1,911^{* * *}$ \\
2 & $-0,012$ & $-0,031$ & $-3,061^{*}$ & $-0,015$ & $-0,026$ & $-1,887^{* *}$ & $-0,011$ & $-0,031$ & $-2,475^{* * *}$ \\
3 & 0,006 & $-0,025$ & 1,495 & 0,003 & $-0,023$ & 0,418 & 0,006 & $-0,025$ & 1,454 \\
4 & $-0,022$ & $-0,047$ & $-5,778^{*}$ & $-0,019$ & $-0,042$ & $-2,392^{* *}$ & $-0,023$ & $-0,048$ & $-5,241^{* * *}$ \\
5 & $-0,009$ & $-0,056$ & $-2,236^{*}$ & 0,004 & $-0,038$ & 0,506 & $-0,012$ & $-0,06$ & $-2,724^{* * *}$ \\
6 & 0,006 & $-0,05$ & 1,662 & 0,007 & $-0,031$ & 0,848 & 0,006 & $-0,054$ & 1,43 \\
7 & 0,003 & $-0,047$ & 0,834 & 0,003 & $-0,028$ & 0,32 & 0,003 & $-0,051$ & 0,769 \\
8 & $-0,013$ & $-0,06$ & $-3,421^{*}$ & $-0,001$ & $-0,029$ & $-0,170$ & $-0,016$ & $-0,067$ & $-3,710^{* * *}$ \\
9 & 0,01 & $-0,05$ & 2,484 & 0,011 & $-0,018$ & 1,450 & 0,009 & $-0,058$ & 2,048 \\
10 & 0,003 & $-0,047$ & 0,694 & $-0,001$ & $-0,019$ & $-0,088$ & 0,004 & $-0,054$ & 0,812 \\
11 & 0,001 & $-0,046$ & 0,181 & 0,003 & $-0,016$ & 0,352 & 0,000 & $-0,054$ & 0,029 \\
\hline
\end{tabular}

Signifikansi pada 0,05 $\left(\mathrm{T}_{\text {tabel }} 1,669\right)^{*}$; Signifikansi pada $0,05\left(\mathrm{~T}_{\text {tabel }} 1,782\right)^{* *}$; Signifikansi pada $0,05\left(\mathrm{~T}_{\text {tabel }} 1,675\right)^{* * *}$

bat peristiwa pengeboman pada 14 Januari 2016 selama tiga hari berturut turut yaitu pada $t_{0}$ dengan thitung $-2,811$, $\mathrm{t}_{1}$ dengan thitung $-1,911$, dan $\mathrm{t}_{2}$ dengan thitung $-2,475$, ketiganya memperlihatkan bahwa nilai thitung yang lebih besar dari ttabel.

Pada tabel 3 juga terlihat bahwa kelompok perusahaan dengan fundamental baik memperlihatkan sentimen negatif yang signifikan hanya pada $t_{2}$ dan $t_{4}$, sedangkan pada kelompok perusahaan dengan fundamental yang kurang baik hal tersebut diperlihatkan pada $t_{0}, t_{1}, t_{2}, t_{4}, t_{5}, t_{8}$, dan t9. Dengan demikian berdasarkan perhitungan thitung ditemukan bahwa terdapat perbedaan sentimen dari kelompok perusahaan dengan fundamental baik dan fundamental yang kurang baik pada saat terjadinya peristiwa pengeboman 14 Januari 2016. Dengan kata lain hal tersebut menunjukkan bahwa faktor fundamental mempengaruhi sentimen investor pada saat melakukan transaksi di pasar modal saat terjadinya peristiwa pengeboman pada 14 Januari 2016. Pembalikan harga yang terjadi dapat diketahui jika AAR pada hari setelah peristiwa signifikan dan bernilai positif. Pembalikan harga juga dapat diketahui melalui grafik CAAR.

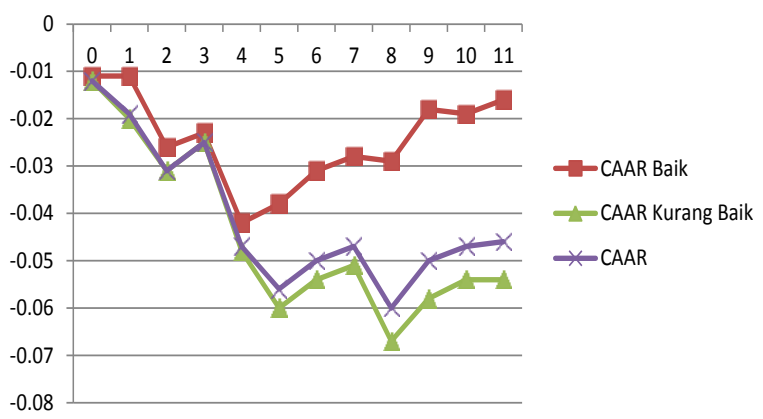

Grafik 2. Cumulative Average Abnormal Return

Berdasarkan Grafik 2 di atas terlihat bahwa peristiwa pengeboman tersebut menyebabkan ter- jadinya overreaction yang berkepanjangan, apabila dilihat dari CAAR keseluruhan sebagian besar event window tren menunjukkan kecenderungan menurun, pembalikan harga sebenarnya sudah terjadi pada $t_{3}, t_{6}$, dan $t_{7}$, dimana harga sempat naik tapi kemudian mengalami penurunan, bahkan pada ts terjadi penurunan tajam yang signifikan. Tren yang sama juga ditunjukkan oleh CAAR kelompok perusahaan kurang baik. Peristiwa pembalikan harga benar-benar baru terjadi pada hari ke sembilan setelah peristiwa, hal tersebut menunjukkan bahwa peristiwa pengeboman tersebut mengakibatkan terjadinya overreaction yang berkepanjangan setelah peristiwa. Berbeda dengan keduanya, pada kelompok perusahaan yang baik meskipun beberapa kali telah terjadi pembalikan harga setelah terjadinya peristiwa, sampai pada hari kesebelas setelah peristiwa belum ada pembalikan harga yang signifikan. Hal tersebut menunjukan bahwa secara keseluruhan pasar modal mengalami overreaction akibat peristiwa pengeboman tersebut terutama pada kelompok perusahaan dengan fundamental kurang baik.

Hasil tersebut juga didukung oleh Tabel 2, pada tabel tersebut memperlihatkan bahwa AR secara keseluruhan pada hari ketiga diperoleh AR positif tetapi tidak signifikan. Bahkan pada hari kedelapan setelah sebelumnya terjadi AR posistif pada hari keenam dan tujuh, terjadi penurunan yang tajam dan signifikan yaitu -0,013. Kemudian pembalikan harga baru terjadi pada t9 dengan nilai AR positif dan signifikan sebesar 0,01 dan thitung 2,484. Hal serupa terjadi pada kelompok perusahaan dengan fundamental kurang baik, dimana pembalikan harga baru terjadi pada t9 dengan nilai AR positif dan signifikan sebesar 0,009 dan thitung 2,048. Sedangkan pada kelompok perusahaan dengan fundamental yang baik sampai pada hari kesebelas setelah peristiwa nilai AR belum menunjukkan nilai yang positif signifikan, 
dengan kata lain pembalikan harga belum terjadi atau tidak terjadi overreaction pada kelompok perusahaan dengan fundamental baik.

\section{Analisis Tambahan}

Ada kemungkinan hasil event study adalah bias karena faktor size effect (Dimson and March, 1986) Hal ini berkaitan dengan stabilitas kinerja pengukuran expected return seperti market adjustments, CAPM and Market Model. Oleh karena itu dilakukan analisis tambahan untuk menguji kemungkinan terjadinya size effect. Analisis tambahan dibedakan berdasarkan abnormal return perusahaan-perusahaan yang masuk pada indeks LQ45 untuk mewakili perusahaan besar yang liquid dan PEFINDO25 untuk mewakili perusahaan kecil dan menengah yang liquid. Pada Tabel 4 menunjukkan bahwa pada saat terjadinya pengeboman pada 14 Januari 2016 pada kedua kelompok perusahaan diperoleh nilai AAR negatif sebesar -0,014 pada kelompok perusahaan besar dan -0,009 pada kelompok perusahaan kecil.

Tabel 4. Tabel Signifikansi Average Abnormal Return LQ45 dan PEFINDO25 Selama Periode Pengujian

\begin{tabular}{ccccccc}
\hline \multicolumn{3}{c}{ LQ45 } & \multicolumn{3}{c}{ PEFINDO25 } \\
\hline $\mathrm{t}$ & AAR & CAAR & THitung & AAR & CAAR & THitung \\
\hline 0 & $-0,014$ & $-0,014$ & $-2,846^{*}$ & $-0,009$ & $-0,009$ & $-1,411$ \\
1 & $-0,006$ & $-0,020$ & $-1,278$ & $-0,007$ & $-0,016$ & $-1,131$ \\
2 & $-0,015$ & $-0,035$ & $-3,195^{*}$ & $-0,005$ & $-0,021$ & $-0,791$ \\
3 & 0,006 & $-0,030$ & 1,163 & 0,006 & $-0,015$ & 0,936 \\
4 & $-0,025$ & $-0,055$ & $-5,126^{*}$ & $-0,018$ & $-0,033$ & $-2,744^{*}$ \\
5 & $-0,010$ & $-0,064$ & $-2,006^{*}$ & $-0,007$ & $-0,040$ & $-1,031$ \\
6 & 0,007 & $-0,057$ & 1,451 & 0,005 & $-0,034$ & 0,821 \\
7 & 0,005 & $-0,052$ & 1,129 & $-0,001$ & $-0,035$ & $-0,141$ \\
8 & $-0,014$ & $-0,066$ & $-2,899^{*}$ & $-0,012$ & $-0,047$ & $-1,813^{*}$ \\
9 & 0,007 & $-0,059$ & 1,520 & 0,014 & $-0,033$ & 2,123 \\
10 & $-0,001$ & $-0,060$ & $-0,283$ & 0,010 & $-0,023$ & 1,570 \\
11 & 0,004 & $-0,056$ & 0,723 & $-0,004$ & $-0,028$ & $-0,690$ \\
\hline
\end{tabular}

Signifikansi pada 0,05 (T $\left.\mathrm{T}_{\text {tabel }} 1,682\right)^{*}$;

Signifikansi pada $0,05\left(\mathrm{~T}_{\text {tabel }} 1,714\right)^{* * *}$

Dari tabel di atas terlihat bahwa pada saat peristiwa pengeboman $\left(t_{0}\right)$ terdapat sentimen negatif yang signifikan pada kelompok perusahaan besar. Sedangkan pada kelompok perusahaan kecil dan menengah memperlihatkan AAR negatif tapi tidak signifikan akibat peristiwa pengeboman pada 14 Januari 2016. Berdasarkan hasil pengolahan data AAR peristiwa pengeboman di Sarinah, Jakarta pada tanggal 14 Januari 2016 menyebabkan terjadinya sentimen negatif bagi para investor terutama pada perusahaan besar. Hal tersebut dapat dimaknai adanya fenomena size effect. Disisi lain dapat dibaca bahwa Indeks LQ45 mewakili 45 saham perusahaan yang paling likuid dengan tingkat transaksi yang tinggi, sehingga pada saat terjadi peristiwa pengeboman saham perusahaan pada Indeks LQ45, investor dapat dengan cepat dapat melakukan transaksi jual atas saham tersebut

Tabel 5. Tabel Signifikansi Average Abnormal Return LQ45 Selama Periode Pengujian

\begin{tabular}{ccccccc}
\hline \multicolumn{4}{c}{ LQ45 Bagus } & \multicolumn{3}{c}{ LQ45 Kurang Bagus } \\
\hline $\mathrm{t}$ & AAR & CAAR & THitung $^{*}$ & AAR & CAAR & THitung* $^{* *}$ \\
\hline 0 & $-0,011$ & $-0,011$ & $-1,381$ & $-0,015$ & $-0,015$ & $-2,496^{* *}$ \\
1 & 0,000 & $-0,010$ & 0,047 & $-0,009$ & $-0,025$ & $-1,549$ \\
2 & $-0,015$ & $-0,025$ & $-1,887^{*}$ & $-0,016$ & $-0,041$ & $-2,585^{* *}$ \\
3 & 0,003 & $-0,022$ & 0,418 & 0,007 & $-0,034$ & 1,113 \\
4 & $-0,019$ & $-0,041$ & $-2,392^{*}$ & $-0,028$ & $-0,062$ & $-4,555^{* *}$ \\
5 & 0,004 & $-0,037$ & 0,506 & $-0,017$ & $-0,078$ & $-2,708^{* *}$ \\
6 & 0,007 & $-0,030$ & 0,848 & 0,007 & $-0,071$ & 1,180 \\
7 & 0,003 & $-0,028$ & 0,320 & 0,007 & $-0,064$ & 1,136 \\
8 & $-0,001$ & $-0,029$ & $-0,170$ & $-0,020$ & $-0,084$ & $-3,335^{* *}$ \\
9 & 0,011 & $-0,018$ & 1,450 & 0,005 & $-0,079$ & 0,875 \\
10 & $-0,001$ & $-0,018$ & $-0,088$ & $-0,002$ & $-0,081$ & $-0,280$ \\
11 & 0,003 & $-0,016$ & 0,352 & 0,004 & $-0,077$ & 0,633 \\
\hline
\end{tabular}

Signifikansi pada $0,05\left(\mathrm{~T}_{\text {tabel }} 1,761\right)^{*}$

Signifikansi pada $0,05\left(\mathrm{~T}_{\text {tabel }} 1,701\right)^{* * *}$

Hasil pengolahan data AAR pada perusahaan yang termasuk pada Indeks LQ45 berdasarkan fundamentalnya (PER dan EVA) selama event window, menunjukkan bahwa pada saat terjadinya pengeboman pada 14 Januari 2016 pada perusahaan LQ45 bagus diperoleh nilai AAR negatif tidak signifikan sebesar -0,011 thitung sebesar 1,381, sedangkan pada perusahaan besar dan kurang bagus diperoleh nilai AAR negatif signifikan sebesar -0,015 thitung sebesar -2,496. Dengan demikian peristiwa pengeboman di Sarinah pada 14 Januari 2016 lebih berdampak negatif pada perusahaan LQ45 yang fundemalnya kurang bagus. Hal tersebut dapat terjadi karena investor juga mempertimbangkan mengenai kondisi fundamental perusahaan dalam pengambilan keputusan investasinya pada saat terjadinya peristiwa pengeboman.

\section{Pembahasan}

Peristiwa pengeboman di Sarinah, Jakarta pada tanggal 14 Januari 2016 menyebabkan terjadinya sentimen negatif bagi para investor. Hal tersebut sesuai dengan yang disampaikan oleh Aktas dan Oncu (2006) bahwa peristiwa tak terduga dapat memberi tekanan lebih pada pasar keuangan, dan dapat membawa sentimen negatif para investor terhadap pasar modal sehingga menyebabkan pelaku pasar mungkin kehilangan kemampuan mereka untuk melakukan penilaian secara rasional. Penelitian ini menunjukkan bahwa peristiwa pengeboman di Sarinah tersebut merupakan peristiwa yang relevan dan mempunyai 
kandungan informasi yang kemudian direspon negatif oleh pasar modal. Kondisi tersebut terlihat dari abnormal return yang menunjukkan adanya sentimen negatif atas peristiwa pengeboman yang terjadi pada 14 Januari 2016 di Sarinah. Insiden ledakan dan letusan tembakan di Sarinah, Jakarta membuat tak hanya membuat panik Jakarta, dunia pun turut menyoroti peristiwa tersebut.

Hasil penelitian ini juga sejalan dengan penelitian Chen dan Siems (2004), yang melakukan penelitian terhadap pengaruh pasar modal global terhadap 14 peristiwa terorisme yang terjadi dari tahun 1951 sampai dengan 2001. Penelitian tersebut memperlihatkan bahwa 33 pasar modal dunia menunjukkan sentimen negatif akibat serangan teroris di WTC 11 September 2001. Dari 33 pasar modal di dunia, 31 diantaranya memiliki abnormal return negatif dan signifikan. Selain itu hasil penelitian ini juga mendukung penelitian yang dilakukan oleh Utama dan Hapsari (2012); Kumar and Liu (2013); Aurangzeb and Dilawer (2012); Baker (2014); Najaf (2017) bahwa secara umum serangan terorisme menyebabkan terjadinya sentimen negatif bagi para investor.

Hasil penelitian ini memperlihatkan bahwa pada saat peristiwa pengeboman pada 14 Januari 2016 kedua kelompok perusahaan menunjukkan nilai abnormal return negatif. Namun dampak yang lebih besar dialami oleh kelompok perusahaan dengan fundamental kurang baik. Terjadinya perbedaan reaksi atas peristiwa pengeboman pada 14 Januari 2016 antara kelompok perusahaan dengan fundamental baik dan kurang baik dapat memberi dugaan bahwa investor mempertimbangkan kondisi fundamental atau kinerja keuangan perusahaan atas saham yang dimilikinya sebelum melakukan keputusan transaksi. Dengan demikian perusahaan dengan fundamental yang baik tidak mudah terpengaruh dengan isu-isu yang berasal dari luar perusahaan. Sebaliknya perusahaan yang memiliki fundamental kurang baik nampaknya akan lebih mudah terpengaruh dengan isu-isu yang berasal dari luar perusahaan.

Penelitian ini juga menemukan indikasi terjadinya overreaction baik terhadap saham-saham yang tergabung dalam indeks saham LQ45 maupun PEFINDO25 selama event period. Pada saat terjadinya pengeboman para investor merespon secara berlebihan atas informasi yang ada. Saat menerima informasi yang buruk pelaku pasar cenderung menjual saham secara berlebihan sehingga mengakibatkan harga mengalami penurunan secara tidak wajar. Selanjutnya fenomena ini akan berbalik saat pasar menyadari telah bereaksi berlebihan (Sembiring et a., 2016). Pembalikan harga juga diduga adanya peran aparat ke- amanan yang cepat mengatasi peristiwa terorisme sehingga dapat mengembalikan kepercayaan investor. Meskipun Indonesia sudah beberapa kali mengalami peristiwa pengeboman bukan berarti investor sudah kebal terhadap informasi yang berkaitan dengan peristiswa terorisme bahkan dianggap sebagai peristiwaa yang dianggap dramatis yang mengakibatkan investor mengalami kepanikan sehingga menyebabkan peningkatan tekanan jual yang tinggi. Rahmawati dan Suryani (2005) juga menyatakan bahwa suatu peristiwa yang dianggap dramatis oleh para investor, dapat menyebabkan para investor bereaksi secara berlebihan (overreaction), yang menyebabkan para investor akan melakukan hal-hal yang mungkin tidak rasional terhadap transaksi saham.

\section{KESIMPULAN DAN SARAN}

Penelitian ini berusaha menganalisis sentimen investor pada peristiwa pengeboman di Sarinah pada 14 Januari 2016 diperoleh hasil bahwa terdapat sentimen negatif atas peristiwa pengeboman tersebut terhadap saham-saham yang tergabung dalam indeks saham LQ45 maupun PEFINDO25. Namun jika dipilah menurut kondisi fundamental perusahaan ternyata pada kelompok perusahaan dengan fundamental baik menunjukkan bahwa pasar tidak menunjukkan adanya sentimen negatif yang signifikan, sebaliknya pada kelompok perusahaan dengan fundamental yang kurang bagus mengalami sentimen negatif yang signifkan bahkan mengarah pada terjadinya overreaction.

Penelitian ini bukan tanpa keterbatasan, dalam penelitian ini hanya menganalisis tidak memerhatikan kondisi pasar, apakah pasar berada dalam kondisi bearish atau bullish karena hanya menganalisis satu peristiwa sehingga untuk penelitian mendatang perlu melibatkan beberapa peristiwa yang sejenis atau yang bersifat bad news agar dapat diketahui apakah kondisi pasar juga berpengaruh atas sentimen pasar.

\section{DAFTAR PUSTAKA}

Aktas, H. \& Oncu, S. (2006). The Stock Market Reaction to Extreme Events: The Evidence from Turkey. International Research Journal of Finance and Economics, 6, 78-85.

Ali, R., Ahmad, Z. \& Anusakumar, S.V., (2011). Stock Market Overreaction and Trading Volume: Evidence From Malaysia. Asian Academy of Management Journal of Accounting and Finance, 7(2), 103-119.

Amyulianthy, R., \& Ritonga, E.K. (2016). The Effect Of Economic Value Added And Earning Per 
Share to Stocks Return (Panel Data Approachment). International Journal of Business and Management Invention, 5(2), 8-15.

Aurangzeb, I \& Dilawer, T. 2012. Impact of Terrorism on Stock returns: Evidence from Pakistan. Universal Journal of Management and Social Sciences, 2(8), 73-85.

Arkan, T. (2016). The Importance of Financial Ratios in Predicting Stock Price Trends: A Case Study in Emerging Markets. Finanse, Rynki Finansowe, Ubezpieczenia, 1(79), 13-26

Baker, D.M.A. (2014). The Effects of Terrorism on the Travel and Tourism Industry. International Journal of Religious Tourism and Pilgrimage, 2(1), 57-67.

Baker, M., \& Wurgler, J. (2006). Investor Sentiment and the Cross-Section of Stock Returns. The Journal of Finance, 61(4), 1645-1680.

Barberis, N., Shleifer, A., \& Vishny, R. (1998). A Model of Investor Sentiment. Journal of Financial Economics, 49(3), 307-343.

Chen, A.H., \& Siems, T. F. (2004). The Effects of Terrorism on Global Capital Markets. European Journal of Political Economy, 20(2), 349-366.

De Bondt, W.F.M., \& Thaler, R, (1985). Does the Market Overreact?. The Journal of Finance, 40(3), 793-805.

DeLong, J. B., Shleifer, A., Summers, L.A., \& Waldmann, R.J. 1990. Noise Trader Risk in Financial Markets. Journal of Political Economy, 98(4): 703-38.

Detik (2016). Pasca Ledakan di Sarinah, IHSG Anjlok 1,72\%, (http://finance.detik.com/read/ 2016/ 01/14/121723/3118347/6/pasca-ledakan-disarinah-ihsg-anjlok-172) Finance Yahoo (2016). finance.yahoo.com.

Dimson, E. \& Marsh, P. Event study methodologies and the size effect: The case of UK press recommendations. Journal of Financial Economics, 17(1) 113-142.

Drakos, K. (2010). Terrorism Activity, Investor Sentiment, and Stock Returns. Review of Financial Economics, 19(3), 128-135.

Drakopoulou, V.(2015). A Review of Fundamental and Technical Stock Analysis Techniques. Journal of Stock \& Forex Trading, 5(1): 1-8

Fama, E.F. (1970). Efficient capital market: a review of theory and empirical work. Journal of Finance 25, 383 - 417.

Jegadeesh, N. (1990). Evidence of predictable behavior of security returns. Journal of Finance, 45, 881-898.

Johnston, R.B., \& Nedelescu, O.M. 2005. The Impact of Terrorism on Financial Markets. IMF Working Paper. 5. 1-22.
Kheradyar, S. Ibrahim, I., \& Nor, F.,M.(2011) Stock Return Predictability with Financial Ratios International Journal of Trade. Economics and Finance, 2(5): 391-396.

Kumar, S., \& Liu, J. 2013. Impact of Terrorism on International Stock Markets. Journal of Applied Business and Economics, 14(2), 42-60.

Lehmann, B. (1990). Fads, martingales, and market efficiency. Quarterly Journal of Economics, $105,1-28$.

MacKinlay, A.C. (1991). Event Studies in Economics and Finance. Journal of Economic Literature, 35(1), 13-39.

Mehrani, K, Roodposhti, F.R, Nekomaram, H., and Saedi, A. 2016. Behavioral trading strategies and investor sentiment: Empirical research in Tehran Stock Exchange (TSE). Indonesian Capital Market Review, 8, 94-109.

Menike M. G. P. D. \& U. S. Prabath . (2014). The Impact of Accounting Variables on Stock Price: Evidence from the Colombo Stock Exchange, Sri Lanka. International Journal of Business and Management, 9(5) : 123-137.

Najaf, R. (2017). Effect of Terrorism on the International Business in Pakistan. Journal of Accounting \& Marketing, 6(1), 1-3.

Rahmawati \& Suryani, T.(2005). Over Reaksi Pasar Terhadap Harga Saham Perusahaan Manufaktur di Bursa Efek Jakarta. SNA, 8, 64-74.

Raharja, B., S., Syhaeli, D., Mranani, M.(2017). Research of stock price overreaction and investor overconfidence Issues. Business, Management and Education, 15(1): 127-139.

Sembiring, F.M., Rahman, S., Effendi, N., \& Sudarsono, R.(2016). Capital Asset Pricing Model in Market Overreaction Conditions: Evidence from Indonesia Stock Exchange. Polish Journal of Management Studies, 14(2), 182-191.

Sirait, R.S., \& Tiswiyanti, W, Mansur, F. (2012). Dampak Pergantian Menteri Keuangan RI Tahun 2010 terhadap Abnormal Return Perusahaan Perbankan yang Terdaftar di BEI. $e$-Jurnal Binar Akuntansi, 1(1), 14-22.

Supramono, Widhiastuti, W. \& Utami, I.(2017) Market Reaction to Cabinet Reshuflle: The Indonesian Evidence. International Journal of Economics and Financial Issue, 7(5) : 183-188.

Utama, C.A. \& Hapsari, L. (2012). Jenis Industri, Kepemilikan Saham Asing Dan Reaksi Pasar Modal Akibat Serangan Bom Teroris. Jurnal Akuntansi dan Keuangan Indonesia, 9(2): 100116. 
Vinetha, S. D. \& Krinakumar, K. (2015). Overreaction and Underreaction in Stock Market: A Review. International Journal of Research in Business Management, 3(3): 49-56.

Venkates, C., K., Tyagi, M., Ganesh, L. (2012). Fundamental analysis and stock returns: An Indian evidence. Global Advanced Research Journal of Economics, Accounting and Finance, 1(2): 3339.
Yong Fang (2013) Empirical Study on Overreaction and Underreaction in Chinese Stock Market Based on ANAR-TGARCH Model. Journal of Financial Risk Management, 2(4) 71-76.

Yull, E., \& Kirmizi. (2012). Analisis Overreaction Hypothesis dan Pengaruh Ukuran Perusahaan, Bid-Ask Spread, dan Likuiditas Saham Terhadap Fenomena Price Reversal: (Studi Empiris Pada Perusahaan yang Terdaftar di BEI). Pekbis Jurnal, 4(1): 1-16. 